\title{
Effects of methacholine induced bronchoconstriction and procaterol induced bronchodilation on cough receptor sensitivity to inhaled capsaicin and tartaric acid
}

\author{
Masaki Fujimura, Sayuri Sakamoto, Yumie Kamio, Tamotsu Matsuda
}

\begin{abstract}
Background The direct effect of bronchoconstriction on cough receptor sensitivity is unknown, and the antitussive effect of $\beta_{2}$ adrenergic agonists in man has been controversial. This study was designed to throw light on these questions.

Methods The threshold of the cough response to inhaled capsaicin, a stimulant acting on $C$ fibre endings, and tartaric acid, a chemostimulant, was measured before and 10 minutes after inhalation of methacholine, which caused a nearly $20 \%$ fall in forced expiratory volume in one second $\left(\mathrm{FEV}_{1}\right)$, in 14 normal subjects (study 1 ), and also before and 30 minutes after inhalation of procaterol (30 $\mu \mathrm{g})$, placebo, and saline in eight normal subjects (study 2 ). Progressively increasing concentrations of capsaicin and tartaric acid solutions were inhaled for 15 seconds by mouth tidal breathing at one minute intervals and cough threshold was defined as the lowest concentration of capsaicin and tartaric acid that elicited five or more coughs.
\end{abstract}

Results In study 1 the geometric mean values of the cough threshold of response to capsaicin and tartaric acid before methacholine callenge, 2.98 (GSE 1.30) $\mu \mathrm{g} / \mathrm{ml}$ and $46.6(1.22) \mathrm{mg} / \mathrm{ml}$, were not significantly different from those of the response to methacholine inhalation, $3.45(1.33) \mu \mathrm{g} / \mathrm{ml}$ and $32.9(1.37) \mathrm{mg} / \mathrm{ml}$. In study 2 the geometric mean value of the cough threshold of response to capsaicin before inhalation of procaterol $(4.61$ (GSE 1.84) $\mu \mathrm{g} / \mathrm{ml}$ ) was not different from that after inhalation of procaterol (4.61 (GSE 1.84) $\mu \mathrm{g} / \mathrm{ml}$ ), which had significant bronchodilator effects. The cough threshold was not altered by placebo or saline.

Conclusions These findings suggest that muscarinic receptor stimulation, bronchoconstriction, $\beta_{2}$ receptor stimulation, or bronchodilation might have no direct effect on the sensitivity of the cough receptors in normal subjects.

Cough is a very common presenting symptom in general practice and the chest clinic.
Although it has been established that cough may be the sole manifestation in patients with asthma and bronchodilators such as $\beta_{2}$ adrenergic agonists and theophylline relieve the cough, ${ }^{12}$ whether bronchodilators have an antitussive effect on cough induced by conditions other than asthma has been a matter of controversy. ${ }^{3}$ Salem and Ariado ${ }^{4}$ proposed that cough receptors are stimulated by local bronchoconstriction rather than through direct interaction with the stimulus. Some evidence, however, suggests that cough occurs independently of bronchoconstriction. ${ }^{56}$ Indeed, we have practical experience of bronchodilator resistant cough that is completely relieved by histamine $\mathrm{H}_{1}$ blockers or corticosteroids, or both (unpublished data). This study was conducted to determine whether changes in bronchomotor tone, $\beta_{2}$ adrenergic agonists, and muscarinic agonists influence the sensitivity of cough receptors to inhaled cough stimuli. We examined the effects of methacholine induced bronchoconstriction and procaterol induced bronchodilation on the threshold of cough in response to inhaled tartaric acid and capsaicin in normal subjects.

\section{Methods}

SUBJECTS

Fourteen normal 20 year old women participated in study 1 (table 1) and another eight normal women, with a mean age of 20.4 (range 20-21) years, participated in study 2. All subjects were non-smokers, had no respiratory symptoms, and had not had a viral infection for at least four weeks. Informed consent was obtained from all subjects. These studies were approved by the ethics committee of our university hospital.

\section{MEASUREMENT OF COUGH SENSITIVITY}

We determined the cough threshold as an index of cough receptor sensitivity by the method we have described previously. ${ }^{7}$ Tartaric acid (Wako Pure Chemical Industries Ltd, Tokyo) was dissolved in physiological (normal) saline to make solutions of $1 \cdot 56,3 \cdot 12,6 \cdot 25,12 \cdot 5,25$, $50,100,200,400$ and $800 \mathrm{mg} / \mathrm{ml}$. Capsaicin $(30.5 \mathrm{mg}$ ) was dissolved in Tween $80(1 \mathrm{ml})$ and ethanol (1 ml) and then in normal saline $(8 \mathrm{ml})$ to make a stock solution of $3.05 \mathrm{mg} / \mathrm{ml}$ $\left(1 \times 10^{-2} \mathrm{~mol} / \mathrm{l}\right)$, which was stored at $-20^{\circ} \mathrm{C}$. 
Table 1 Details of the subjects

\begin{tabular}{|c|c|c|c|c|c|}
\hline $\begin{array}{l}\text { Subjects } \\
\text { No }\end{array}$ & $\begin{array}{l}F V C \\
(l)\end{array}$ & $\begin{array}{l}\% \text { FVC } \\
\text { (\% pred) }\end{array}$ & $\begin{array}{l}F E V_{1} \\
(l)\end{array}$ & $\begin{array}{l}\% F E V_{1} \\
\text { (\% pred) }\end{array}$ & $\begin{array}{l}P C_{20} \text { meth } \\
(\mathrm{mg} / \mathrm{ml})\end{array}$ \\
\hline \multicolumn{6}{|l|}{ STUDY 1} \\
\hline 1 & $3 \cdot 35$ & 106 & $3 \cdot 21$ & 105 & $2 \cdot 5$ \\
\hline 2 & $2 \cdot 64$ & 86 & $2 \cdot 29$ & 78 & $1 \cdot 25$ \\
\hline 3 & 3.47 & 116 & 3.35 & 117 & 40 \\
\hline 4 & 3.49 & 107 & $3 \cdot 24$ & 101 & 40 \\
\hline 5 & 3.03 & 100 & $2 \cdot 91$ & 101 & 20 \\
\hline 6 & $3 \cdot 17$ & 104 & 3.04 & 103 & 40 \\
\hline 7 & $4 \cdot 22$ & 127 & 3.65 & 111 & 80 \\
\hline 8 & 2.99 & 96 & $2 \cdot 87$ & 95 & 40 \\
\hline 9 & 3.02 & 97 & $2 \cdot 88$ & 96 & $1 \cdot 25$ \\
\hline 10 & $3 \cdot 78$ & 121 & $3 \cdot 27$ & 108 & 80 \\
\hline 11 & $2 \cdot 45$ & 79 & $2 \cdot 33$ & 78 & $5 \cdot 0$ \\
\hline 12 & 3.98 & 128 & $3 \cdot 73$ & 124 & 20 \\
\hline 13 & $3 \cdot 36$ & 104 & $3 \cdot 25$ & 103 & 40 \\
\hline 14 & 3.53 & 106 & $3 \cdot 29$ & 100 & $5 \cdot 0$ \\
\hline \multicolumn{6}{|l|}{ STUDY 2} \\
\hline 1 & $2 \cdot 69$ & 85 & $2 \cdot 19$ & 76 & \\
\hline 2 & $3 \cdot 47$ & 99 & $2 \cdot 83$ & 90 & \\
\hline 3 & $2 \cdot 44$ & 74 & 1.89 & 63 & \\
\hline 4 & $2 \cdot 34$ & 73 & $2 \cdot 23$ & 76 & \\
\hline 5 & $4 \cdot 36$ & 118 & $3 \cdot 40$ & 103 & \\
\hline 6 & 3.69 & 110 & $3 \cdot 13$ & 103 & \\
\hline 7 & $2 \cdot 88$ & 87 & $2 \cdot 70$ & 93 & \\
\hline 8 & $3 \cdot 12$ & 90 & 2.99 & 96 & \\
\hline
\end{tabular}

FVC - forced vital capacity; $\mathrm{FEV}_{1}$-forced expiratory volume in one second; $\mathrm{PC}_{20}$ methprovocative concentration of methacholine producing a $20 \%$ or more fall in $\mathrm{FEV}_{1}$.

This solution was diluted with physiological saline to make solutions of $0.372,0.744,1.49$, $2 \cdot 98,6 \cdot 00,11 \cdot 9,23 \cdot 8,47 \cdot 6,95 \cdot 2$, and $190 \mu \mathrm{g} /$ ml. Subjects inhaled a control solution of normal saline followed by progressively increasing concentrations of the tartaric acid or the capsaicin solution. They inhaled solutions for 15 seconds by mouth tidal breathing, wearing a nose clip, every 60 seconds from a Bennett Twin nebuliser (3012-60 ml, Puritan-Bennett Company, Carlsbad, California), inhaling increasing concentrations until they coughed at least five times. The nebuliser output was $0 \cdot 21$ $\mathrm{ml} / \mathrm{min}$. The cough threshold was defined as the lowest concentration of the cough stimuli that elicited five or more coughs.

\section{METHACHOLINE INDUCED}

BRONCHOCONSTRICTION

Bronchoconstriction was produced by methacholine inhalation. The provocative concentration of methacholine causing a $20 \%$ or greater fall in the forced expiratory volume in one second $\left(\mathrm{FEV}_{1}\right)$-the $\mathrm{PC}_{20}$ meth-was determined (table 1). Methacholine was dissolved in physiological saline to make solutions of $0 \cdot 04,0 \cdot 08,0 \cdot 16,0 \cdot 31,0 \cdot 63,1 \cdot 25,2 \cdot 5,5$, $10,20,40,80$, and $160 \mathrm{mg} / \mathrm{ml}$. Methacholine was inhaled from a Devilbiss 646 nebuliser (Devilbiss Company, Somerset, Pennsylvania) operated by compressed air at $51 / \mathrm{min}$. The nebuliser output was $0.28 \mathrm{ml} / 2 \mathrm{~min}$. Subjects inhaled methacholine for two minutes by mouth tidal breathing, wearing a nose clip, and $\mathrm{FEV}_{1}$ was measured with a dry wedge spirometer (Transfer Test, PK Morgan Ltd, Chatham, Kent). Increasing concentrations were inhaled until FEV, fell by $20 \%$ or more.

STUDY DESIGN

Study 1 : effect of bronchoconstriction on cough receptor sensitivity

The tartaric acid or capsaicin cough threshold was determined before and 10 minutes after inhalation of the $\mathrm{PC}_{20}$ concentration of methacholine or saline for two minutes. Three spirometric measurements were carried out at one minute intervals on three occasions (before and immediately after methacholine inhalation and after the post-methacholine measurement of cough threshold) to ensure that the cough threshold was determined during methacholine induced bronchoconstriction. The best $\mathrm{FEV}_{1}$ value of the three measurements on each occasion was kept for data analysis. When all the measurements were completed a $\beta_{2}$ adrenergic agonist, salbutamol, was inhaled to relieve the bronchoconstriction.

\section{Study 2: Effect of bronchodilation on cough receptor sensitivity}

The capsaicin cough threshold was determined before and 30 minutes after inhalation of $30 \mu \mathrm{g}$ of procaterol or placebo (freon gas alone) from a metered dose inhaler or inhalation of saline from a Devilbiss 646 nebuliser for two minutes. Partial and maximum expiratory flow-volume curves were produced by the method of Barnes and coworkers ${ }^{8}$ on two occasions, before the control measurement of capsaicin cough threshold and before the cough threshold measurement after the test drug had been inhaled, to evaluate the bronchodilator effect of the test drug. Maximum expiratory flow at $25 \%$ forced vital capacity (FVC) on the partial expiratory flow-volume curve $\left(\mathrm{PEF}_{25}\right)$ and $\mathrm{FEV}_{1}$ were measured as indices of bronchomotor tone. The curve with the largest FVC out of three partial and full flow-volume curves produced at one minute intervals was retained for analysis on each occasion.

\section{DATA ANALYSIS}

Cough threshold values are given as geometric means, with the geometric standard error of the mean (GSE) expressed as a factor, and values of FVC, $\mathrm{FEV}_{1}$, and $\mathrm{PEF}_{25}$ as arithmetic means and standard errors of the mean (SE).

We have compared geometric mean values for the cough threshold before and after methacholine induced bronchoconstriction (study 1) and before and after procaterol induced bronchodilation (study 2) by Student's paired $t$ test. A p value of 0.05 or less is taken as significant.

\section{Results}

STUDY 1: EFFECT OF METHACHOLINE ON COUGH RECEPTOR SENSITIVITY

Tartaric acid cough threshold

The geometric mean value for the tartaric acid cough threshold was $46.6($ GSE 1.22$) \mathrm{mg} / \mathrm{ml}$ before inhalation of methacholine and 32.9 (GSE 1.37) $\mathrm{mg} / \mathrm{ml}$ afterwards (fig 1), a nonsignificant difference. Saline inhalation did not alter the cough threshold (40.5 (GSE 1.29) mg/ $\mathrm{ml}$ before and $37.8(1.69) \mathrm{mg} / \mathrm{ml}$ after saline; fig 2). There was also no difference between the cough thresholds before inhalation of methacholine and of saline or between the cough thresholds after inhalation of methacholine and 

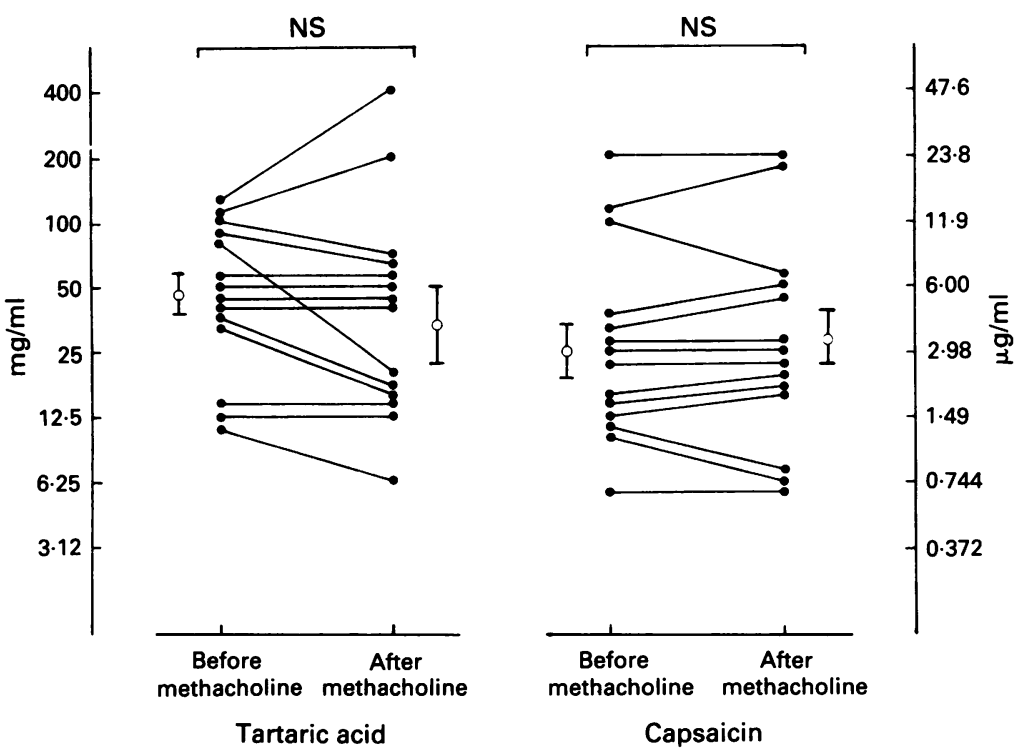

Figure 1 Threshold of cough response to tartaric acid and capsaicin before and after methacholine induced bronchoconstriction in 14 normal subjects. Each open circle with bar represents the geometric mean value with the geometric standard error of the mean.

of saline. Furthermore, the ratio of the cough threshold after methacholine inhalation to the initial value was 0.99 (SE 0.27), which was not significantly different from the ratio of the cough threshold after saline inhalation to the initial value, $1.02(0 \cdot 13)$. As shown in table $2, \mathrm{FEV}_{1}$ fell significantly immediately after inhalation of methacholine and after the post-methacholine determination of the tartaric acid cough threshold. Inhalation of saline did not change $\mathrm{FEV}_{1}$.

\section{Capsaicin cough threshold}

The capsaicin cough threshold was 2.98 (GSE 1.30) $\mu \mathrm{g} / \mathrm{ml}$ before methacholine inhalation and 3.45 (GSE 1.33) $\mu \mathrm{g} / \mathrm{ml}$ afterwards, a non-significant difference (fig 1). The cough threshold was not influenced by inhalation of saline (fig 2). There was no difference between
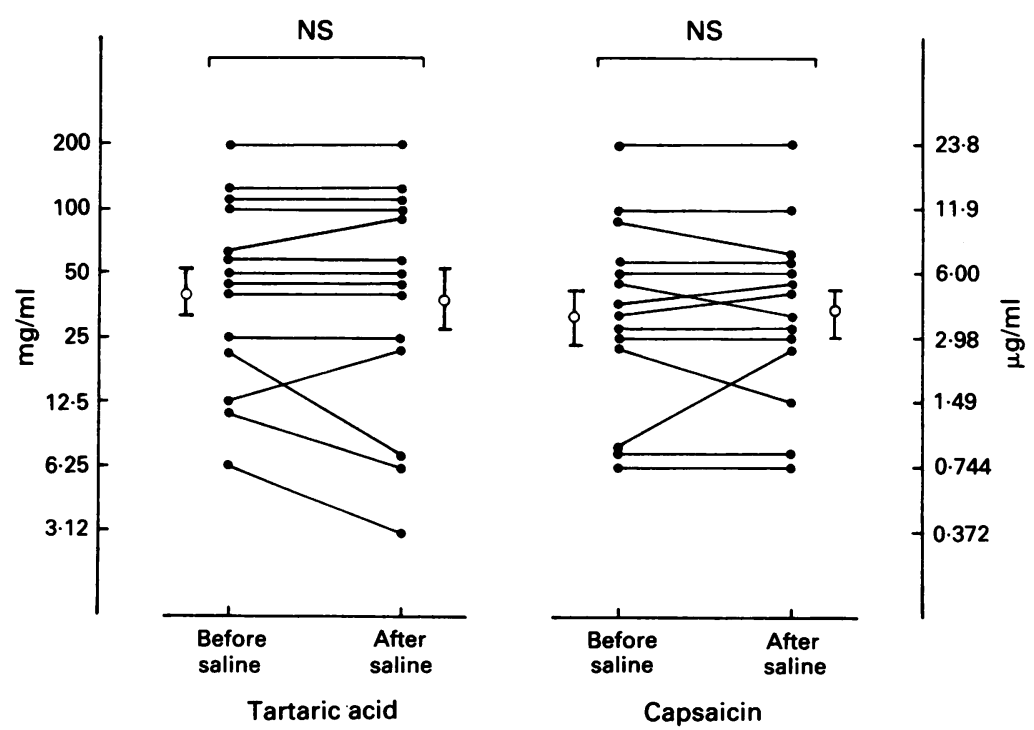

Figure 2 Threshold of the cough response to tartaric acid and capsaicin before and after inhalation of saline in 14 normal subjects. Each open circle with bar represents the geometric mean value with the geometric standard error of the mean. the cough threshold before inhalation of methacholine and saline or after inhalation of methacholine and saline. The ratios of the cough threshold after inhalation of methacholine and saline to each initial value were $1 \cdot 20$ (SE 0.18) and 1.25 (SE 0.24), again a non-significant difference. As shown in table 2, the decrease in $\mathrm{FEV}_{1}$ was significant after inhalation of methacholine and after the post-methacholine determination of the cough threshold. Saline inhalation had no influence on $\mathrm{FEV}_{1}$.

\section{STUDY 2: EFFECT OF PROCATEROL ON COUGH} RECEPTOR SENSITIVITY

The geometric mean value of the capsaicin cough threshold was 4.61 (GSE 1.84 ) $\mu \mathrm{g} / \mathrm{ml}$ before inhalation of procaterol and 4.61 (GSE $1.84) \mu \mathrm{g} / \mathrm{ml}$ afterwards (fig 3 ). There was no significant difference between these values. The cough threshold was not altered by inhalation of placebo or saline (3.54 $(1.68) \mu \mathrm{g} / \mathrm{ml}$ before placebo and $4.21(1.79) \mu \mathrm{g} / \mathrm{ml}$ after placebo; $5.00(1.87) \mu \mathrm{g} / \mathrm{ml}$ before saline and $4.61(1.79)$ $\mu \mathrm{g} / \mathrm{ml}$ after saline(fig 3 ). There were no differences among the cough thresholds before inhalation of procaterol, placebo, and saline, and the cough thresholds after these inhalations did not differ from each other. As shown in table 3, $\mathrm{FEV}_{1}$ and $\mathrm{PEF}_{25}$ were significantly increased by inhalation of procaterol, whereas neither $\mathrm{FEV}_{1}$ nor $\mathrm{PEF}_{25}$ was significantly influenced by placebo or saline.

\section{Discussion}

Cough usually results from the stimulation of sensory nerves in the airway. ${ }^{9}$ The larynx has two types of cough receptors: myelinated irregularly firing irritant receptors ${ }^{10}$ and nonmyelinated $C$ fibre endings. ${ }^{11}$ The tracheobronchial tree has also two types of cough receptors: myelinated rapidly adapting stretch receptors (or "irritant receptors") 12 and nonmyelinated bronchial $C$ fibre endings. ${ }^{13}$ In this study we used tartaric acid and capsaicin to provoke cough. It has been proposed that chemostimulants such as citric acid elicit cough mainly by stimulating irritant receptors. ${ }^{3}$ In this study we used tartaric acid as a tussive agent, which is considered to be a chemostimulant like citric acid, though details of its mode of action are not well understood. It has been postulated that capsaicin, on the other hand, the active ingredient of red pepper, produces cough mainly by stimulating $\mathrm{C}$ fibre endings. ${ }^{314} 15$ Inhaled capsaicin probably acts mainly on the larynx, trachea, and major bronchi, which are areas with the greatest sensitivity for provocation of cough. ${ }^{1617}$ Although the larynx may be the initial site of cough stimulation, the sublaryngeal airways may also contribute to the response, as patients who have had a laryngectomy still cough when they inhale capsaicin through their tracheostomy tubes. ${ }^{18}$

Irritant receptors are located in the airway wall and it has been proposed that they are probably influenced by the airway deformation caused by smooth muscle contraction because bronchoconstriction agents have been found to 
Table 2 Mean (SE) FEV, values before and after inhalation of methacholine or saline and after measurement of tartaric acid or capsaicin cough threshold after methacholine or saline inhalation in 14 normal subject

\begin{tabular}{|c|c|c|c|}
\hline & \multicolumn{3}{|l|}{$F E V_{1}(l)$} \\
\hline & Baseline & $\begin{array}{l}\text { After inhalation of } \\
\text { methacholine or saline }\end{array}$ & $\begin{array}{l}\text { After } 2 \text { nd cough } \dagger \\
\text { provocation }\end{array}$ \\
\hline \multicolumn{4}{|c|}{ Tartaric acid provocation } \\
\hline $\begin{array}{l}\text { Saline } \\
\text { Methacholine }\end{array}$ & $\begin{array}{l}3.07(0.11) \\
3.09(0.11)\end{array}$ & $\begin{array}{l}3.02(0.11) \\
2.51(0 \cdot 10)^{\star}\end{array}$ & $\begin{array}{l}2.97(0.11) \\
2.46(0.09)^{\star}\end{array}$ \\
\hline \multicolumn{4}{|c|}{ Capsaicin provocation } \\
\hline $\begin{array}{l}\text { Saline } \\
\text { Methacholine }\end{array}$ & $\begin{array}{l}3.03(0.11) \\
3.07(0.11)\end{array}$ & $\begin{array}{l}3.03(0 \cdot 11) \\
2 \cdot 46(0 \cdot 14)^{\star}\end{array}$ & $\begin{array}{l}3.04(0.11) \\
2.57(0.13)^{\star}\end{array}$ \\
\hline
\end{tabular}

${ }^{\star} \mathrm{p}<0.001$ by comparison with the baseline value.

$\dagger$ Ten minutes after methacholine or saline inhalation.

activate irritant receptors. ${ }^{19}$ On the other hand, there is some evidence that cough occurs independently of bronchoconstriction. ${ }^{56}$ Eschenbacher et $\mathrm{al}^{5}$ reported that alteration of the osmolarity of inhaled aerosols caused cough and bronchoconstriction but absence of a permanent anion caused cough alone. Simonsson and coworkers ${ }^{20}$ also showed that atropine reduced citric acid induced bronchoconstriction but not citric acid induced cough in patients with asthma. To our knowledge, a direct effect of bronchoconstriction and muscarinic agonists on cough receptor sensitivity has not been reported. This study was conducted to examine whether or not methacholine induced bronchoconstriction enhances the cough induced by inhaled capsaicin and tartaric acid and to confirm that inhaled $\beta_{2}$ agonists have no direct effect on the cough elicited by inhaled capsaicin. The doseresponse curve for capsaicin induced cough is reliably reproducible when the challenge is repeated after an interval of more than 15 minutes, ${ }^{21}$ as was the case in both our studies. As saline or placebo hardly altered individual cough thresholds in this study, the reproducibility of our method is considered to be good.

In normal subjects our results showed that

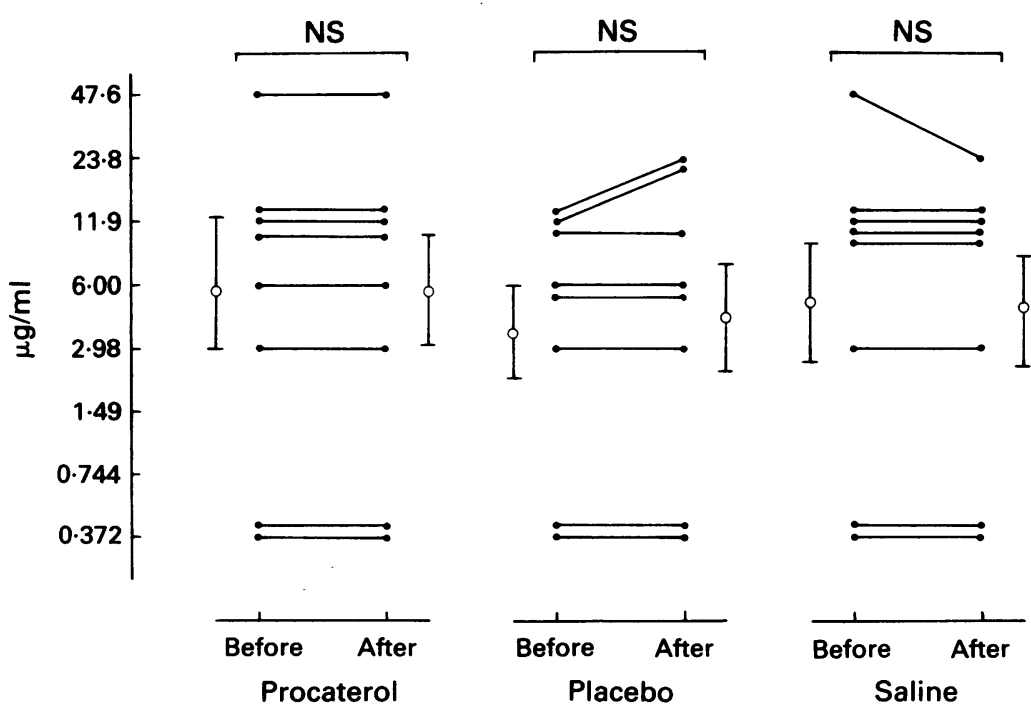

Figure 3 Threshold of the cough response to capsaicin before and after inhalation of procaterol, placebo, and saline in eight normal subjects. Each open circle with bar represents the geometric mean value with the geometric standard error of the mean.
Table 3 Mean ( $S E) F E V$, and peak expiratory flow $\left(P E F_{25}\right)$ values before and after inhalation of procaterol, placebo, or saline in eight normal subjects

\begin{tabular}{llll}
\hline & $F E V_{1}(l)$ & & $P E F_{25}(l / s)$ \\
\cline { 2 - 2 } & Baseline $\begin{array}{l}\text { After } \\
\text { inhalation }\end{array}$ & Baseline $\begin{array}{l}\text { After } \\
\text { inhalation }\end{array}$ \\
\hline Saline & $2.79(0.19) 2.76(0.19)$ & & $1.66(0.16) 1.47(0.14)$ \\
Placebo & $2.67(0.18) 2.70(0.20)$ & & $1.40(0.21) 1.53(0.18)$ \\
Procaterol & $2.75(0.19) 2.83(0.19) \dagger$ & $1.55(0.11) 2.42(0.23) \ddagger$
\end{tabular}

*Thirty minutes after inhalation of procaterol, placebo, or saline.

tp $<0.02$ compared with the baseline value, $\neq \mathrm{p}<0.002$ compared with the baseline value.

inhaled procaterol in a dose of $30 \mu \mathrm{g}$, which was enough to reduce bronchomotor tone (56\% increase in $\mathrm{PEF}_{25}$ ), had no effect on capsaicin induced cough. In addition, inhaling sufficient methacholine to cause at least a $20 \%$ fall in $\mathrm{FEV}_{1}$ did not influence the cough sensitivity to capsaicin and tartaric acid. Inhaled $\beta_{2}$ agonists have been shown to have a role as antitussive agents in some conditions, such as asthma characterised by cough. ${ }^{12}$ In other studies cough induced by distilled water and prostaglandin $F_{2 \alpha}$ was reduced by inhalation of fenoterol in both asthmatic and normal subjects; ${ }^{22-24}$ citric acid induced cough was inhibited by inhaled salbutamol in asthmatic subjects $^{25}$ and bronchoscopy induced cough is attenuated by inhaled fenoterol. ${ }^{26}$ Thus it has been postulated that $\beta_{2}$ agonists may reduce the input from myelinated slowly adapting stretch receptors located in the membranous posterior wall of conducting airways by causing bronchodilation, which could lead to a reduction of the cough reflex, and that they could also have a direct effect on sensory nerves, which may possess inhibitory $\beta_{2}$ receptors, and on epithelium to alter the penetration of the tussive agents to the nerves. ${ }^{3}$ Inhaled salbutamol has been shown to have no effect on cough induced by citric acid and capsaicin in normal subjects. ${ }^{24} 25$ Our findings confirm the lack of effect of inhaled $\beta_{2}$ agonists on capsaicin cough threshold in normal subjects. Accordingly, we may speculate that indirect mechanisms are responsible for the attenuating effect of inhaled $\beta_{2}$ agonists on the cough induced by distilled water and prostaglandin $F_{2} \alpha$, both of which are likely to change the surroundings, the vicinity of cough receptors, perhaps by releasing chemical mediators ${ }^{27}$ and changing epithelial ion transport. Indeed, $\beta_{2}$ agonists have been shown to inhibit an allergic mediator release ${ }^{29} 30$ and inhaled frusemide has been reported to inhibit cough induced by solutions with a low chloride content. ${ }^{31}$ Inhalation of lignocaine, however, has been reported to block cough, but not bronchoconstriction, and sodium cromoglycate to block bronchoconstriction, but not cough. $^{32}$ At present we do not know the mechanism of the indirect antitussive effect of $\beta_{2}$ agonists.

The other main result of this study is that bronchoconstriction induced by methacholine failed to augment the sensitivity of cough receptors to capsaicin and tartaric acid in normal subjects. Our recent studies (un- 
published) indicate that capsaicin inhaled by the method used in this study reaches to relatively peripheral airways as $\mathrm{PEF}_{25}$ fell by a mean of $21 \%$ after inhalation of capsaicin in a cough threshold dose in asthmatic subjects and $7 \cdot 8 \%$ in normal subjects. If bronchoconstriction per se enhances the cough receptor sensitivity of the bronchi, methacholine induced bronchoconstriction could be expected to augment the capsaicin cough sensitivity. Consequently, this study suggests that cough receptor sensitivity may not be directly influenced by bronchoconstriction or bronchodilatation.

1 McFadden ER Jr. Exertional dyspnea and cough as preludes to acute attacks of bronchial asthma. $N$ Engl $J$ Med 1975;292:555-9.

2 Corrao WM, Braman SS, Irwin RS. Chronic cough as the sole presenting manifestation of bronchial asthma. $N$ Engl J Med 1979;330:633-7.

3 Fuller RW, Jackson DM. Physiology and treatment of cough. Thorax 1990;45:425-30.

4 Salem H, Aviado DM. Antitussive drugs. Am J Med Sci 1964;247:585-600

5 Eschenbacher WL, Boushey HA, Sheppard D. Alteration in osmolarity of inhaled aerosols cause bronchoconstriction and cough, but absence of a permeant anion causes cough alone. Am Rev Respir Dis 1984;129:211-5.

6 Godden DJ, Barland C, Lowry R, Higenbottam T. Chemical specificity of coughing in man. Clin Sci 1986; 70:301-6.

7 Fujimura M, Sakamoto S, Kamio Y, Matsuda T. Sex difference in the inhaled tartaric acid cough threshold in non-atopic healthy subjects. Thorax 1990;45:633-4.

8 Barnes PJ, Gribbin HR, Osmanliev D, Pride NB. Partial flow-volume curves to measure bronchodilator doseresponse curves in normal humans. J Appl Physiol 1981, 50:1193-7.

9 Karlsson JA, Sant'Ambrogio G, Widdicombe J. Afferent neural pathways in cough and reflex bronchoconstriction. $J$ Appl Physiol 1988;65:1007-23.

10 Boushey HA, Richardson JG, Widdicombe JG, Wise JC The response of laryngeal afferent fibres to mechanical and chemical stimuli. J Physiol Lond 1974;240:153-75.

11 Boushey HA, Richardson PS, Widdicombe JG. Reflex effects of laryngeal irritation of the pattern of breathing and total lung resistance. J Physiol Lond 1972;224:501-13.

12 Bartlett D Jr, Jeffery P, Sant'Arbrogio G, Wise JCM Location of stretch receptors in the trachea and bronchi of the dog. J Physiol London 1976;258:409-20.

13 Jammes Y, Fomaris E, Mei SS, Barrat E. Afferent of efferent components of the bronchial vagal branches in cats. J Autonomous Nervous System 1982;5:165-76.
14 Coleridge HM, Coleridge JCG. Impulse activity in afferent vagal C-fibres with endings in the intrapulmonary airways of dogs. Respir Physiol 1977;29:125-42.

15 Lundberg JM, Saria A. Capsaicin-induced desensitization of airway mucosa to cigarette smoke, machanical and chemical irritants. Nature 1983;302:251-3.

16 Widdicombe JG. Receptors in the trachea and bronchi of the cat. J Physiol 1954;123:71-104.

17 Sant'Ambrogio JM. Information arising from the tracheobronchial tree of mammals. Physiol Rev 1982;62:531-69.

18 Pounsford JC. Studies on the cough reflex in man. MD thesis, University of London, 1990

19 Vidruk EH, Hahn HL, Nadel JA, Sampson SR. Mechanisms by which histamine stimulates rapidly adapting receptors in dog lungs. $J$ Appl Physiol 1977;43:397-402.

20 Simonsson BG, Jacobs FM, Nadel JA. Role of autonomic nervous system and the cough relfex in the increased responsiveness of airways in patients with obstructive airway disease. J Clin Invest 1967;46:1812-8.

21 Collier JG, Fuller RW. Capsaicin inhalation in man and the effects of sodium cromoglycate. Br J Pharmacol 1984 81:113-7.

22 Lowry R, Higinvottam T, Johnson T, Godden D. Inhibition of artificially induced cough in many bronchodilators. $\mathrm{Br} J$ Clin Pharmacol 1987;24:503-10.

23 Lowry R, Wood A, Johnson T, Higenbottam T. Antitussive properties of inhaled bronchodilators of induced cough. Chest 1988;93:1186-9.

24 Nichol G, Nix A, Barnes PJ, Chung KF. Prostaglandin F enhancement of capsaicon induced cough in man: modu-

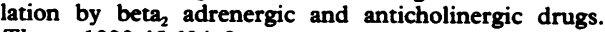
Thorax 1990;45:694-8.

25 Pounsford JC, Birch MJ, Saunders KB. Effect of bronchodilators of the cough response to inhaled citric acid in normal and asthmatic subjects. Thorax 1985;40:662-7.

26 Vesco D, Kleisbauer J, Oreheck J. Attenuation of bronchofiberscopy-induced cough by an inhaled beta ${ }_{2}$-adrenergic agonist, fenoterol. Am Rev Respir Dis 1988;138.805-6.

27 Hopp RJ, Bewtra AK, Nair NM, Townley RG. Effect of terfenadine of the bronchoconstriction induced by ultrasonically nebulized distilled water. Ann Allergy ultrasonically

28 Pasargiklian M, Bianco S, Allegra L. Clinical, functional and pathogenetic aspects of bronchial reactivity to prostaglandins $\mathrm{F}_{2,}, \mathrm{E}_{1}$ and $\mathrm{E}_{2}$. Adv Prost Throm Res 1976:1:461-75.

29 Butchers PR, Fullarton JR, Skidmore IF, Thompson LE Vardey CJ, Wheeldon A. A comparison of the antianaphylactic activities of salbutamol and disodium cromogrycate in the rat, the rat mast cell and in human lung tissue. Br J Pharmacol 1979;67:23-32.

30 Fujimura M, Sakamoto S, Nishi K, Saito M, Miyake Y, Matsuda T. Inhibitory effect of inhaled procaterol on anaphylactic bronchoconstriction and thromboxane production in guinea pigs. Clin Exp Allergy 1991;21:189-94

31 Ventresca PG, Nichol GM, Barnes PJ, Chung KF. Inhaled furosemide inhibits cough induced by low chloride content solutions but not by capsaicin. Am Rev Respir Dis 1990;142:143-6.

32 Sheppard D, Rizk NW, Boushey HA, Bethel RA. Mechanism of cough and bronchoconstriction induced by distilled water aerosol. Am Rev Respir Dis 1983;127:691-4. 